\title{
Awareness Is Not Enough: Frequent Use of Water Pollution Information and Changes to Risky Behavior
}

\author{
Ashley D. Ross ${ }^{1, *}$, Abbey Hotard ${ }^{1}$, Manoj Kamalanathan ${ }^{2}{ }^{\mathbb{D}}$, Rayna Nolen ${ }^{2}$, David Hala ${ }^{2}$, \\ Lauren A. Clay ${ }^{3,4} \mathbb{D}$, Karl Kaiser ${ }^{1}$ and Antonietta Quigg ${ }^{2}(\mathbb{D}$ \\ 1 Department of Marine and Coastal Environmental Science, Texas A\&M University at Galveston, \\ Galveston, TX 77544, USA; ahotard@tamu.edu (A.H.); kaiserk@tamug.edu (K.K.) \\ 2 Department of Marine Biology, Texas A\&M University at Galveston, Galveston, TX 77554, USA; \\ manojka@tamu.edu (M.K.); r_nolen@tamu.edu (R.N.); halad@tamug.edu (D.H.); quigga@tamug.edu (A.Q.) \\ 3 Department of Health Administration and Public Health, D'Youville College, Buffalo, NY 14201, USA; \\ clayl@dyc.edu \\ 4 School of Global Public Health, New York University, New York, NY 10003, USA \\ * Correspondence: ashleydross@tamug.edu
}

Received: 19 September 2020; Accepted: 16 October 2020; Published: 20 October 2020

\begin{abstract}
Hazard information plays an important role in how risk perceptions are formed and what actions are taken in response to risk. While past studies have shown that information on water and air pollution is associated with changes to individual behavior, there is a need for examination of water quality information in the context of environmental disturbances. This study fills that gap by examining water pollution in an active industrial region of the United States-the Galveston Bay of Texas. Using original survey data collected in 2019 of 525 adults living in the Galveston Bay region, logistic regression was used to analyze the association of awareness and use of water pollution information on changes to outdoor activities and consumption of drinking water and/or seafood. Controls for chronic and acute exposure to environmental hazards, environmental knowledge and experience, and demographics were included in the model. The findings indicate frequent use of water quality information is significantly associated with action to reduce risk. On average, an individual who checks water pollution monitoring every day is $26 \%$ and $33 \%$ more likely to change their outdoor activities and consumption behavior, respectively, than someone who is not aware of this information. There is a need for improvement in pollution data collection and the development of a risk communication framework that facilitates the dissemination of this information in relevant, accessible, and credible ways.
\end{abstract}

Keywords: hazard mitigation; water quality; pollution information

\section{Introduction}

While much attention is paid to structural mitigation in reducing hazard risk, the role of hazard information in risk reduction is often overlooked. Yet, hazard information is critical to understanding and managing the risk people face. From the lens of risk as a product of exposure and vulnerability [1], hazard information can be understood as a resource influencing social vulnerability [2]. Where environmental hazard and monitoring information is lacking or difficult to access, interpret, or use-as is often the case in racial and ethnic minority communities-vulnerability is heightened [3]. From the lens of risk as socially and culturally constructed, hazard information is interpreted by individuals in relation to their worldviews as well as experience [4-6]. People carefully weigh multiple influences of risk on their well-being and develop coping strategies in response; then they re-evaluate the stressor, available resources, and coping strategies in relation to changes in the characteristics, 
conditions, and context of the stressor and their own coping abilities $[4,7,8]$. In this iterative process, external information is important to the initial risk assessment and development of coping responses [9]. Hazard information, therefore, is an important factor influencing perceptions of and responses to risk.

Reducing risk is the aim of hazard mitigation, which "takes the form of advance action designed to eliminate or reduce the long-term risk to human life and property from natural and man-made hazards" [10]. Brody and Atoba [11] categorized hazard mitigation to include strategies that avoid through retreat and relocation, resist through structural mitigation, accommodate through the creation of spaces and structures that absorb the impact of a periodic hazard, or build awareness through education and information. Past research has found that mitigation in the form of hazard education can build awareness. For example, education has been an essential tool for near-source mitigation of the National Tsunami Hazard Mitigation Program, and surveys of residents in the states of California, Oregon, and Washington demonstrated the campaigns raised awareness [12]. However, the education programs did not change individual behaviors. Residents prescribed action to reduce tsunami risk as a government, not personal responsibility. This calls into question if building awareness is sufficient for hazard mitigation-does risk reduction rely on behavioral adaptations?

Multiple studies have found hazard information awareness to be associated with changes in behavior. Wen, Balluz, and Mokdad [13] analyzed changes in behavior related to awareness of air quality alerts. Using data from a national survey of U.S. adults conducted in 2005, they found that the prevalence of change in outdoor activity increased to $68 \%$ (from 16\%) and 75\% (from 31\%)-among individuals without and with lifetime asthma, respectively-when accounting for awareness of air quality reports as well as individual perception of air quality. Similarly, a study conducted by Reams and colleagues [14] of residents of the upper Industrial Corridor of Louisiana found that individuals who are aware of air quality forecasts-and check them often-were more likely to change their behavior in order to limit their exposure to environmental risk. Additionally, the analyses indicated that higher levels of knowledge and concern about environmental hazards and more recent experience with storms, floods, and other disruptive environmental events encourage individuals to take action to make themselves safer. A subsequent study by Reams and Irving [15], focused on the industrial corridor of Orleans and St. Tammany Parishes in Louisiana, supported these findings. Analyses of a survey of 550 residents suggested that individuals who were aware of and frequently checked air quality forecasts were more likely to adopt exposure reducing behaviors by altering their outdoor activities on days with poor air quality. Studies of water quality advisories have found congruent changes in behavior, including decreases in surfing and beach-going following advisories for fecal contamination of coastal waters [16] and general compliance with boil water advisories $[17,18]$.

The present study extended this line of inquiry to examine risk-reducing behaviors related to awareness of water pollution in the context of environmental hazards in the Galveston Bay region of Texas. As a center of oil and gas and transportation industrial activity, the Lower Galveston Bay watershed can be considered a testbed for interactions between society, the environment, and industry. Residents of the tri-county area surrounding the Bay face both chronic exposure to water pollutants as well as acute exposure related to man-made, environmental hazard events-two of which were examined in this study: the Deer Park Intercontinental Terminals Company facility chemical fire (17 March 2019) and a barge collision in the Houston Ship Channel involving oil tankers (10 May 2019). Human-induced emergencies and disasters such as these are not uncommon. As illustrated in Figure 1, oil and chemical spills have affected coastlines and waterways across the United States (U.S.). The data, capturing oil and chemical spill incidents reported to the National Oceanic and Atmospheric Administration (NOAA) from 1968 to 2020 [19], also demonstrate an increase in these environmental disturbances over time.

Given the chronic problem of environmental disturbances and the corresponding threat to water quality, it is imperative to understand how individual use of water pollution monitoring information in this context is associated with action to reduce risk. To our knowledge, past studies have not addressed awareness and use of water quality information among a representative population and in relation 
to multiple types of behavioral adaptation. The present study fills this gap by using survey data of 525 adults living in the three counties around Galveston Bay to test the hypothesis:

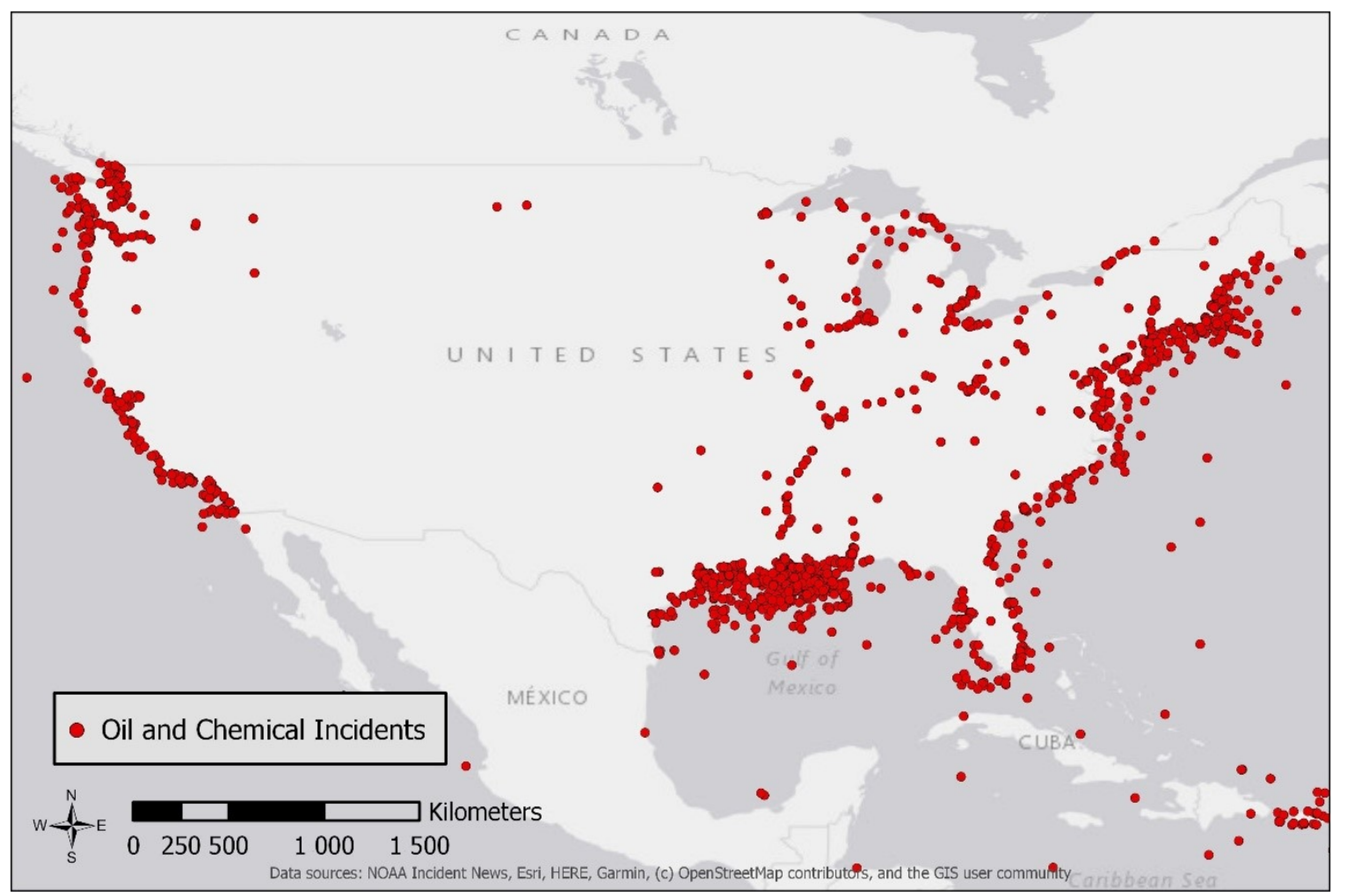

Figure 1. The map depicts sites of oil and chemical incidents occurring 13 December 1968-3 September 2020 as reported in the National Oceanic and Atmospheric Administration (NOAA) IncidentNews raw data (https://incidentnews.noaa.gov/raw/index). The map uses Esri's Light Grey Canvas Basemap.

Individuals who are aware of water pollution monitoring and check it frequently will be more likely to change their behavior that may put them at risk than those who are not aware of pollution monitoring or check it infrequently.

\section{Background: Water Pollutants in Galveston Bay}

\subsection{Galveston Bay Environmental and Socioeconomic Attributes}

The Galveston Bay watershed consists of approximately $62,160 \mathrm{~km}^{2}$ of land and water, with a mere $1554 \mathrm{~km}^{2}$ covered by the Bay. The Galveston Bay estuary is a hydrodynamically shallow system $(2.1 \mathrm{~m})[20]$ that is heavily influenced by wind and freshwater inflows from the Trinity and San Jacinto Rivers [21]. The western side of the Bay is occupied by the metropolis of Houston, which comprises the fifth-largest metropolitan area in the United States; the eastern side remains largely agricultural and undeveloped. Galveston Bay supports a diverse number of fish, wildlife, and wetland plants. It provides ecosystem services in the form of storing and cycling essential nutrients, absorbing and detoxifying pollutants, maintaining the hydrologic cycle, and moderating the local climate [22,23]. For humans, services also include providing sites for employment, including the oil and gas and commercial fishing industries, and recreation such as fishing, birding, and boating [24].

Most critical for water quality, the Galveston Bay region supports three major ports and a robust petrochemical industry that processes approximately 14 percent of the nation's crude oil [25]. Over 8000 vessels annually use the Houston Ship Channel en route to the Ports of Houston, Texas City, and/or Galveston [26,27]. During the 1998-2014 time period, there were on average 275 oil spills each 
year in Galveston Bay [28] with significant spills ( $>4000$ barrels or $>168,000$ gallons) taking place occasionally [29]. Fifty-seven percent of reported spills were from vessels, while $39 \%$ of spills could be traced to land-based facilities.

The propensity of oil-derived polycyclic aromatic hydrocarbons (PAHs) and "legacy" industrial pollutants, including polychlorinated biphenyls (PCBs), to bio-concentrate in organisms, bio-accumulate across food webs, and exert toxicity has led to environmental monitoring efforts [30-33]. Sediments and biota act as reservoirs and refuges for these pollutants in the environment. Such sequestration ensures their long-term persistence, contributing to chronic toxicity in exposed organisms [34-36]. Studies continue to show high levels of PCBs and dioxins in sediment, water, and fish samples taken from the Houston Ship Channel [37-39]. Recent studies suggest that dioxins continue to be released into the environment in and around the ship channel [37,40-43]. Since 1990, PCBs, dioxin, and organochlorine pesticides have been identified as pollutants of concern in seafood consumption advisories issued in the Lower Galveston Bay watershed by the Texas Department of State Health Services $[43,44]$.

\subsection{Environmental Hazards in Galveston Bay}

In 2019, two environmental disturbances occurred in less than two months that spilled approximately 32,000 barrels ( 1 million gallons) of oil-derived products into Galveston Bay. The first occurred on March 17, 2019 at approximately 10:30 a.m. when a storage tank caught fire at the Intercontinental Terminals Company (ITC) facility in Deer Park, Texas, due to a mechanical failure [45]. The tank contained naphtha enriched with butane, a highly flammable liquid used in the production of gasoline [46]. The fire eventually spread to ten other 80,000 barrel storage tanks before being extinguished three days later. These additional storage tanks held stock feeds for gasoline production including xylene and pygas, which contain concentrations of carcinogenic benzene [47]. The fire produced a black plume of smoke visible for 30 miles and a smog-like haze across at least six counties [48]. On the third day of the fire, elevated benzene levels led to a one-day shelter-in-place order in the Deer Park area [49]. Days later, on March 22, a dike wall partially collapsed at the facility allowing chemicals to be released into the Houston Ship Channel; however, no evidence of benzene was found in local drinking water. In all, the Deer Park fire is estimated to have released approximately 16,595 barrels ( $\sim 696,990$ gallons) of oil-contaminated water and 35,714 barrels ( $\sim 1.5$ million gallons) of flame retardants [50].

Less than two months later, on 10 May 2019 at approximately 3:20 p.m., the 236-meter (775-foot) tanker MV Genesis River collided with the tug Voyager pushing two barges in the Houston Ship Channel near Bayport, Texas. One barge capsized, and the other was heavily damaged, leaking approximately 11,276 barrels (473,600 gallons) of product over five days [51]. Each barge contained approximately 25,000 barrels of reformate used in the production of gasoline, which can have high concentrations of benzene [52]. Area residents were told to avoid fishing and coming in contact with the water, and a strong "gasoline smell" was reported across several cities [53]. Water sampling in some areas showed elevated levels of benzene [52], and there were reports of a large fish kill following the spill [51]. By 15 May 2019, both barges were removed from the ship channel and normal vessel traffic resumed [51]. The fishing advisory was lifted on 24 May after water testing no longer showed high levels of contaminants from the event.

\subsection{Health Impacts of Pollutants in Galveston Bay}

At present, the health and ecological impacts of the Deer Park chemical fire and the barge collision in Galveston Bay are not fully known. In the immediate aftermath of the Deer Park fire, the Texas Commission on Environmental Quality released a water quality report that found, in samples taken from the immediate vicinity of the fire, oil-derived hydrocarbon levels that far exceeded mandated health-protective concentrations [54]. Initial public concern was mainly over the release of volatile organic compounds, including benzene [55]. However, subsequent analytical chemical analyses 
showed the absence of volatile organics in water samples [56]. Nonetheless, concern remains for the exposure of aquatic biota to oil-derived hydrocarbons and likely long-term human health effects related to seafood consumption and exposure to these two environmental hazard events.

The International Agency for Research on Cancer [57] classifies heavy oil and related contaminants as carcinogens that may directly increase the risk of cancers through several pathways: stress, immunosuppression, or endocrine disruption. Oil contains several chemical compounds including benzene, toluene, xylene, gasoline, and naphthalene which can dissolve or deform cell membranes and kill cells. Safety information on crude oil indicates that prolonged exposure or repeated contact should be avoided and that vapor, mist, or liquid may be harmful if inhaled [58].

Human health studies of oil exposure, especially those studying long-term health consequences, are limited as there are only seven studies of the health effects on humans exposed to the 39 largest oil spills globally [59]. Recent research on short-term human health effects conducted in the Gulf of Mexico following the Deepwater Horizon oil spill (DWHOS) reports lower respiratory tract symptoms, inflammation of the eyes and throat, nausea, headache, low back pain, and psychological impacts (e.g., depression) among exposed populations [60]. A study of women and their children's health found that among women in Southern Louisiana, physical-environmental exposure such as working on oil clean-up, coming into contact with oil, or damage to property were associated with higher self-reported physical health impacts including: burning in nose, throat, or lungs; sore throat; wheezing; headaches; and watery, burning, itchy eyes or nose [61]. Further, exposure to the DWHOS was a predictor of higher rates of poor mental health in the same cohort of women [62]. The Gulf Long-term Follow-up (GuLF) Study, a cohort study following the health of DWHOS clean-up workers and volunteers, found that working on the spill for more than 180 days and stopping work due to heat exposure were associated with a greater risk of nonfatal myocardial infarction (i.e., heart attack) [63]. The GuLF study also found high amounts of total hydrocarbon exposure or stress on the job were associated with an increased prevalence of depression and PTSD [64].

\section{Materials \& Methods}

\subsection{Survey Sample}

To assess the association of pollution information and changes in the behavior of residents of the Galveston Bay region, we launched an online survey, using a platform provided by Qualtrics, of adults (age 18 years or older) residing in a total of 51 zip codes surrounding Galveston Bay. The survey sample area is shown in Figure 2 in relation to the Deer Park chemical fire and the barge collision; Galveston Beach is also highlighted in the figure. The survey was in the field 28 May-14 July 2020 and collected responses from 525 individuals. All participants were given information about the study before beginning the survey, and the survey protocol was approved by the Texas A\&M University Institutional Review Board (reference number IRB2019-0646M).

Survey respondents were recruited by Qualtrics to fill quotas on sex, age, and race. The quotas represent overall population characteristics of adult residents in the zip codes sampled, determined by the 2018 U.S. Census Bureau data [65]. There were differences between the sample and population proportions with skews towards more females (61\% in the sample versus $50 \%$ in the population), younger adults ( $42 \%$ of 18 - to 34 -year-olds in the sample compared to $34 \%$ in the population), and white respondents ( $43 \%$ in the sample versus $36 \%$ in the population). Given these discrepancies, a sample weight was calculated to adjust the sample to population parameters for sex, age, and race/ethnicity using a "raking" or iterative proportional fitting method [66]. While there are no strict rules on trimming survey weights—and many surveys use different trimming procedures and threshold points [67]—we adopted the procedure used by others [68] to trim observations three times smaller or three times larger than the median weight value. Accordingly, a total of $7 \%$ of the observations were trimmed. While applying the weight to the quota-based sample adjusts the sample to make it more representative of the population, there are unknown biases introduced into the survey estimates [69]. This is due 
to the non-probability sampling frame because measures of precision (i.e., response rate, margins of error) are not available with such a sampling approach. See Table S1 for the sample proportions with and without the weight applied, compared to population proportions.

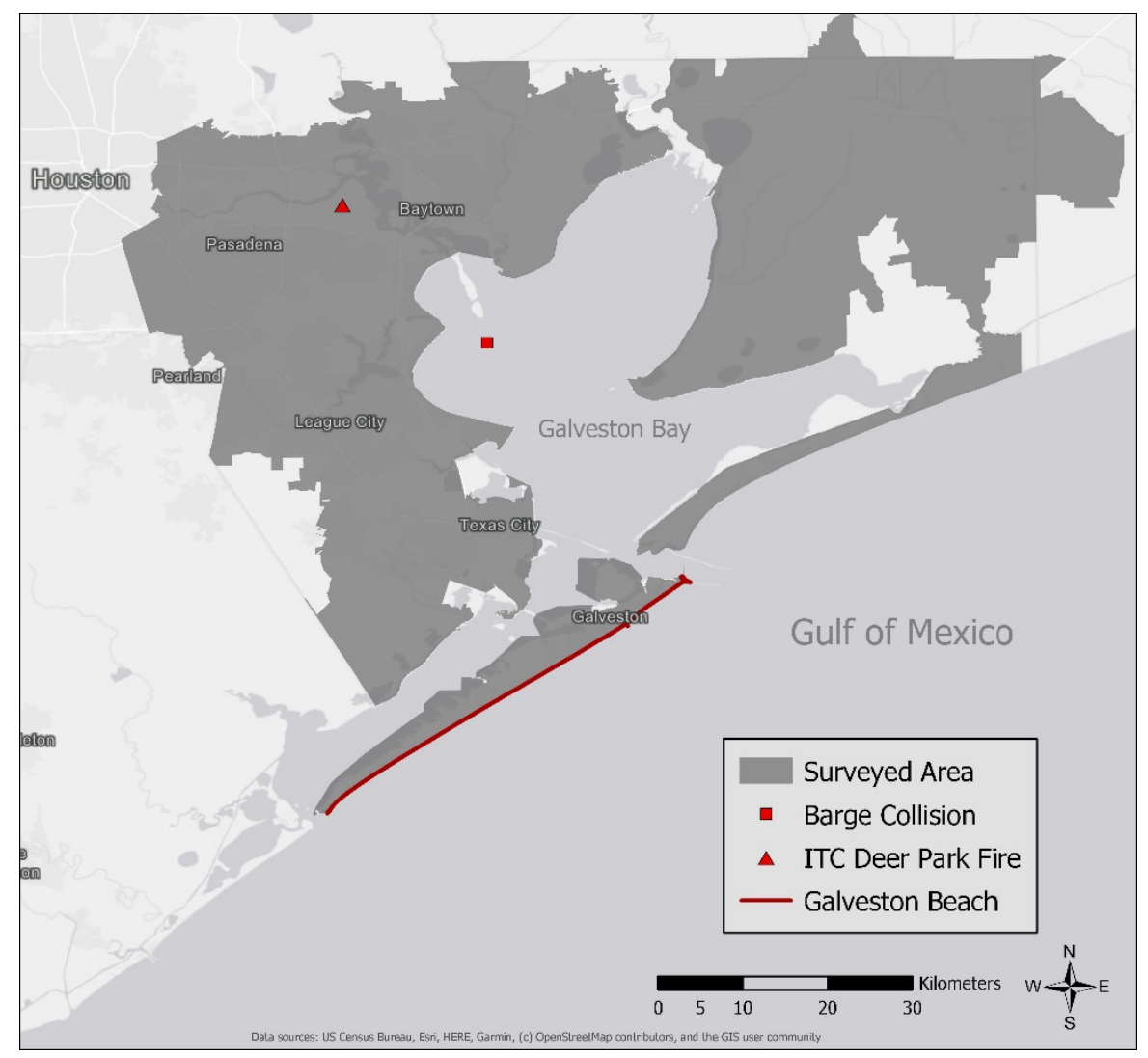

Figure 2. Shaded area corresponds to zip codes sampled in the survey. The map was developed using U.S. Census Bureau 2019 TIGER/Line Shapefile of zip code tabulation areas and Esri's Light Grey Canvas Basemap. Locations for the Deer Park chemical fire and the barge collision were drawn based on event reports [45,51]. Galveston Beach was drawn according to generalized beach access points published by the Texas Parks and Wildlife Department [70]. ITC: Intercontinental Terminals Company.

\subsection{Measures}

To measure the dependent variable of interest—change to behavior-survey respondents were asked two questions: (1) "Have you ever changed your planned outdoor activities for the day due to poor water quality conditions in Galveston Bay?" and (2) "Have you ever changed your use or consumption of drinking water and/or seafood due to poor water quality conditions in Galveston Bay?" Response options included "yes," "no," or "don't know." Observations with responses of "don't know" were dropped from the analysis, leaving 457 and 462 observations to analyze for change to outdoor activities and consumption, respectively. Weighted tabulation of responses to these two questions shows that $44 \%$ of respondents have changed their outdoor activities while $36 \%$ have changed their consumption behavior on days with poor quality conditions in the Bay.

To assess the key independent variable of interest-awareness and frequency of use of water quality information-the survey asked respondents: "Are you aware of any pollution monitoring of the water quality of Galveston Bay?" Responses were limited to "yes" or "no." For those respondents that indicated "yes," they were asked a follow-up question: "And how often do you check the water quality rating of your community? Do you check it ... " Response options included: "don't know," "never," "seldom," "sometimes," "occasionally," and "every day." Responses to these two questions were combined into one variable with the referent category of no awareness of water quality monitoring, 
followed by an increasing frequency of checking water quality ratings. See Table 1 for tabulations of responses, with the survey weight applied, for all independent variables in the model.

Table 1. Tabulations of independent variables analyzed in the regression model.

\begin{tabular}{|c|c|c|}
\hline Variable (Referent Category) & Category & Prevalence $(\mathrm{N}=525)$ \\
\hline \multirow{5}{*}{$\begin{array}{l}\text { Water quality monitoring (not } \\
\text { aware) }\end{array}$} & never check or don't know & $6.15 \%$ \\
\hline & seldom check & $6.62 \%$ \\
\hline & sometimes check & $8.89 \%$ \\
\hline & occasionally check & $7.36 \%$ \\
\hline & every day check & $4.07 \%$ \\
\hline \multirow{7}{*}{$\begin{array}{c}\text { Fish, swim, visit Galveston Bay } \\
\text { (never) }\end{array}$} & once a year & $12.18 \%$ \\
\hline & a couple of times a year & $19.77 \%$ \\
\hline & multiple times a year & $18.52 \%$ \\
\hline & once a month & $11.59 \%$ \\
\hline & multiple times a month & $15.73 \%$ \\
\hline & once a week & $8.97 \%$ \\
\hline & multiple times a week & $4.81 \%$ \\
\hline \multirow{7}{*}{ Eat locally caught seafood (never) } & once a year & $3.83 \%$ \\
\hline & a couple of times a year & $14.77 \%$ \\
\hline & multiple times a year & $22.22 \%$ \\
\hline & once a month & $12.22 \%$ \\
\hline & multiple times a month & $15.72 \%$ \\
\hline & once a week & $8.33 \%$ \\
\hline & multiple times a week & $5.90 \%$ \\
\hline \multirow{8}{*}{ Concern for health (not at all) } & not at all to a little & $4.32 \%$ \\
\hline & a little & $9.55 \%$ \\
\hline & a little to a moderate amount & $8.34 \%$ \\
\hline & a moderate amount & $18.15 \%$ \\
\hline & a moderate amount to a lot & $11.50 \%$ \\
\hline & a lot & $15.81 \%$ \\
\hline & a lot to a great deal & $10.07 \%$ \\
\hline & a great deal & $14.30 \%$ \\
\hline \multirow{4}{*}{$\begin{array}{l}\text { Environmental hazard knowledge } \\
\text { (not at all) }\end{array}$} & slightly & $22.81 \%$ \\
\hline & moderately & $34.79 \%$ \\
\hline & very & $18.88 \%$ \\
\hline & extremely & $11.36 \%$ \\
\hline Pollution experience (none) & at least one event & $91.26 \%$ \\
\hline Sex (male) & female & $50.40 \%$ \\
\hline \multirow{3}{*}{ Age (18-34 years) } & 35-44 years & $18.00 \%$ \\
\hline & 45-64 years & $33.40 \%$ \\
\hline & 65 years and older & $14.90 \%$ \\
\hline Latino (no) & yes & $47.60 \%$ \\
\hline African American (no) & yes & $10.90 \%$ \\
\hline \multirow{3}{*}{ Education level (high school or less) } & some college & $21.02 \%$ \\
\hline & Associate's or Bachelor's degree & $36.68 \%$ \\
\hline & post-graduate degree & $9.79 \%$ \\
\hline
\end{tabular}

Chronic exposure to poor environmental conditions has been connected to behavior modifications in a study of air quality [71]; similarly, it is thought that acute exposure to environmental emergencies and disasters encourages adaptations to reduce risk [72]. Accordingly, the model controls for chronic and acute pollution exposure through multiple measures. Chronic exposure to water pollution in the Galveston Bay was measured by responses to two survey questions that replicate survey items in past studies [15,73]: (1) “How often would you say you fish, swim, or visit Galveston Bay?" and (2) 
"How often do you eat locally caught seafood?" Response options included: "never," "once a year," "a couple of times a year," "multiple times a year but not monthly," "once a month," "multiple times a month but not weekly," "once a week," and "multiple times a week." A third question was asked about the frequency of visiting Galveston Beach. However, the frequency of visiting Galveston Beach was highly correlated with the frequency of swimming, fishing, and visiting Galveston Bay; therefore, it was not included in the model.

Assessment of acute exposure to water pollution focused on the recent environmental hazard events and asked respondents to rate their concerns about health related to these events. Two questions were posed: (1) "How concerned were you about the effect of the Deer Park Fire on your health and the health of your household?" and (2) "How concerned were you about the effect of the barge collision in Galveston Bay on your health and the health of your household?" Response options included: "not at all," "a little," "a moderate amount," "a lot," and "a great deal." Prior to these questions, respondents were asked if they were aware of these events. Regarding the Deer Park chemical fire, 59\% said they were aware of this event, and 50\% were aware of the barge collision. To those that were not aware or said they were not sure, brief descriptions of the events and pictures from local media were shown (see Figure S1). This should have aided recall for some respondents; therefore, the self-reported indicator of health concern to measure acute exposure to the two environmental hazard events should reasonably capture if individuals thought they were physically exposed or experienced anxiety or stress over the event. Due to a high correlation between health concerns for each environmental hazard event, the measure of acute exposure included in the model represents the average concern for the two events. The resulting variable has nine categories, ranging from no concern to "a great deal" of concern.

In addition to chronic and acute pollution exposure, environmental hazard knowledge and prior experience with pollution are controlled for in the model as these have been found to be associated with action to reduce risk $[14,15]$. To measure environmental hazard knowledge, a question replicating items of past studies $[15,73]$ was posed in the survey: "How knowledgeable do you feel you are about actions to take in the event of an environmental hazard? An environmental hazard is the risk of damage to the environment from air pollution, water pollution, toxins, and radioactivity." Response options included: "not knowledgeable at all," "slightly knowledgeable," "moderately knowledgeable," "very knowledgeable," and "extremely knowledgeable."

The survey also presented respondents with a list of pollution types and events, asking: "In your lifetime, have you ever personally seen or experienced the following in or around Galveston Bay?" These included: "tar balls on the beach," "trash and other debris in the water," "trash and other debris on the beach or coastline," "dead fish on the beach or coastline likely due to contamination," "smell of oil or other chemicals," "smell of sewer," and "sheen of oil or other chemicals in the water." Responses that indicated experience with at least one of these is considered to represent pollution experience while responses of "none of these" indicate no experience with pollution. Finally, controls are included for sex (male or female), age (18-34 years, 35-44 years, 45-64 years, and 65 years and older), Latino ethnicity (no or yes), African American race (no or yes), and education level (high school or less, some college, Associate's or Bachelor's degree, or post-graduate degree).

\subsection{Method}

Logistic regression was used to model the likelihood of change in outdoor activities (Model 1) and change in consumption of drinking water or seafood (Model 2) due to poor water conditions in Galveston Bay as explained by awareness and frequency of use of water quality monitoring information while controlling for chronic water pollution exposure (fish, swim, or visit Galveston Bay and eat locally caught seafood), acute water pollution exposure (health concern related to the Deer Park chemical fire and the barge collision), environmental hazard knowledge, pollution experience in and around Galveston Bay, sex, age, race and ethnicity, and education level. Logistic regression is appropriate when the dependent variable is a binomial response variable and when modeling the impacts of multiple explanatory variables on the response variable [74]. 
The survey weight was applied to the logistic regression so that the observations are adjusted to better represent population parameters. The survey weight was also accounted for in the assessment of the goodness-of-fit of the models. Similar to general F-tests that test the null hypothesis that the model is no better than a model fit with only intercept term, goodness-of-fit was assessed using an F-test developed specifically for use with survey data. The F-adjusted mean residual test takes into account survey weights and design and was validated using National Health Interview Survey data [75]. Finally, the results of the logistic regression are explored using marginal effects at specified values because they appropriately express the non-linearity and conditional effects of the results [76].

\section{Results}

The results of the logistic regression analyses indicate that the frequency of use of water pollution monitoring information, acute exposure to environmental hazards, and pollution experience are significantly associated with behavioral changes when there are poor water quality conditions in Galveston Bay. The F-adjusted mean residual goodness-of-fit test was applied and suggested no evidence of lack of fit, indicating the model is correctly specified. Because logistic regression results are difficult to interpret from coefficients, we turn to the marginal effects to explore the findings. See Table S2 for the full regression results, including coefficients and standard errors.

Figure 3 presents the marginal effects of key explanatory variables, expressed as the discrete change in the likelihood of altering behavior to outdoor activities-Model 1, marked by circles-and consumption of drinking water and seafood-Model 2, marked by triangles. Marginal effects like these, expressed at specified values of the independent variables, should be interpreted in relation to the referent category, which is noted in parentheses next to each variable title. Further, confidence intervals that cross zero should be interpreted to indicate statistical insignificance. Note that the demographical control variables as well as some categories of the key explanatory variables are omitted from the figure for presentation purposes (see Table S3).

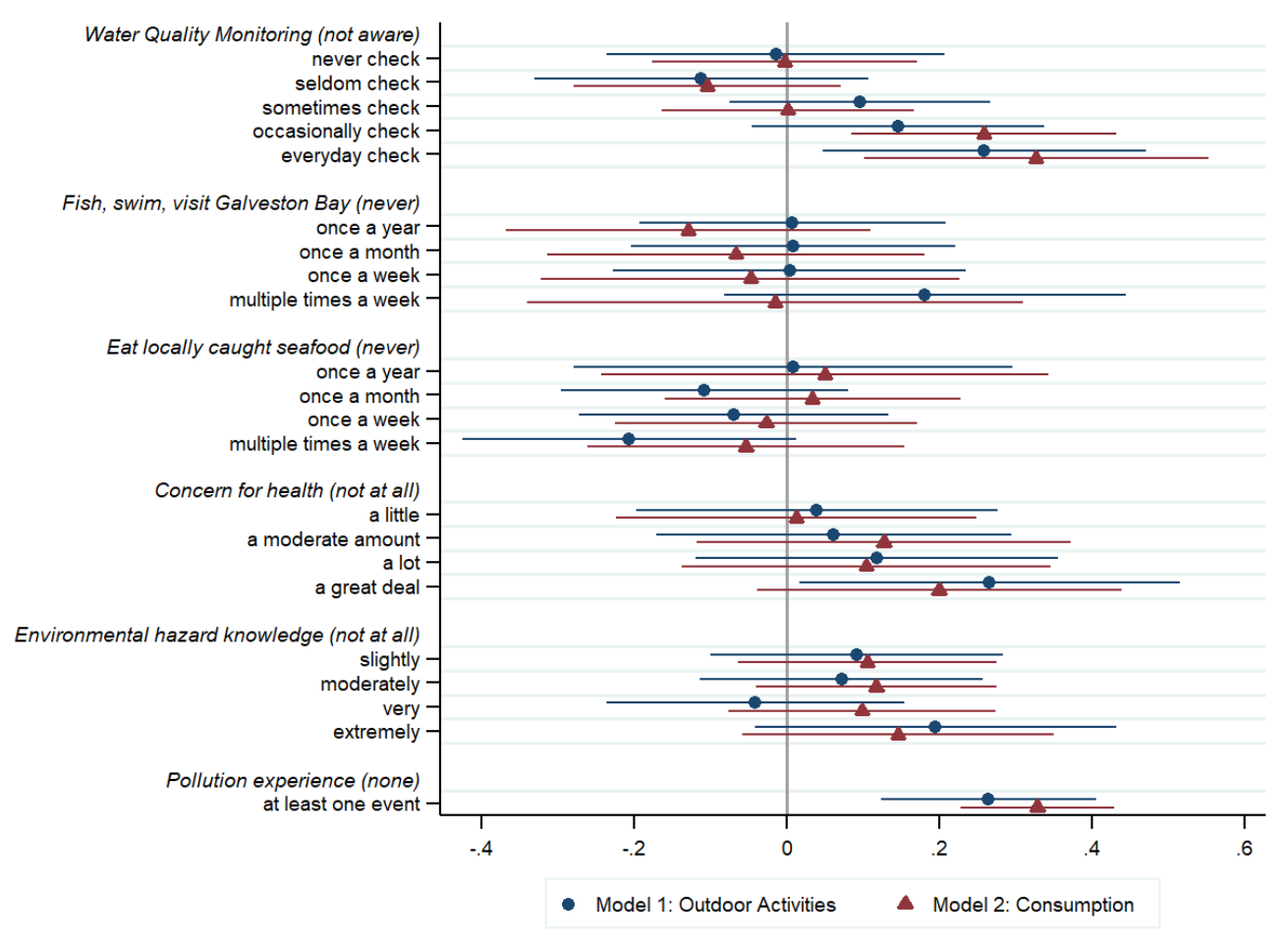

Figure 3. Discrete changes in marginal effects, from the referent category, with $95 \%$ confidence intervals. 
Considering first the primary explanatory variable of interest, the results support that individuals who are aware of water pollution monitoring and check it frequently are more likely to change their behavior than those who are not aware of pollution monitoring or check it infrequently. The marginal effects demonstrate that, on average, an individual who checks water quality information "every day" is $26 \%$ ( $p=0.017)$ more likely than someone who is not aware of water pollution monitoring to change their planned outdoor activities and 33\% $(p=0.005)$ more likely to change their consumption of drinking water and/or seafood than someone unaware of water quality information. Additionally, an average individual who "occasionally" checks water quality ratings is associated with a $26 \%(p=0.004)$ higher likelihood of changing their consumption behavior, compared to someone with no awareness of water quality information. Occasionally checking water quality ratings is not significantly associated with changing outdoor activities, and less frequent use of water pollution information is not significantly associated with changes to either behavior.

The models account for chronic and acute exposure to water pollution. Of these measures, only the concern for health related to recent environmental hazards (the Deer Park chemical fire and the barge collision in Galveston Bay) are associated with changes in behavior that reduce risk. The marginal effects indicate that, on average, an individual who has the highest level of concern ("a great deal") for their health and the health of their household is $27 \%(p=0.036)$ more likely than someone with no concern to change their outdoor activities due to poor water quality. Health concern is not significantly associated with changes to consumption of drinking water and/or seafood, and lower degrees of concern are not significantly associated with changes to outdoor activities or consumption.

In addition to exposure, the model accounts for self-reported environmental hazard knowledge and experience with pollution events in and around Galveston Bay. While environmental hazard knowledge is not statistically significant, pollution experience is significantly associated with action to reduce risk. On average, individuals who have experienced at least one event in their lifetime are $26 \%(p=0.000)$ and $33 \%(p=0.000)$ more likely than someone who has never observed a pollution disturbance to change their outdoor activities and consumption of drinking water and/or seafood, respectively. Finally, in consideration of the demographic control variables, the results indicate that females are $11 \%(p=0.026)$ more likely than males to change their consumption, and 45- to 65-year-old adults are $17 \%(p=0.007)$ less likely than 18 - to 34 -year-old adults to change their outdoor activities.

\section{Discussion}

\subsection{Implications of Findings}

The results support our hypothesis that individuals who are aware of water pollution monitoring and check this information frequently are more likely to take action that reduces their risk in terms of changing their outdoor activities and consumption of drinking water and/or seafood on days when water quality is poor. This is in line with past studies that have found that awareness of air quality reports and frequency of checking them is associated with behaviors to reduce risk $[12,14,15]$. These findings suggest risk-reducing behavior is sensitive to the frequency of checking water quality ratings. While occasionally checking water quality information is significantly associated with changes to consumption, it is not significantly associated with changes to outdoor activities. The findings also indicate that acute, but not chronic, exposure is significantly associated with changes to outdoor activities when water quality is poor. However, changes to consumption in relation to the 2019 environmental hazards are not evident. Additional data, particularly rich qualitative data from interviews and focus groups, would help explore how perceptions of risk are associated with acute exposure events and, in turn, affect the propensity to take different actions to reduce risk. There is some evidence that the fishing public often ignores fish consumption advisories due to discounting health risks that are associated with familiar and enjoyable activities [77]. Similar psychosocial processes involving de-amplification of risk may be occurring among residents in relation to recreational activities in the Galveston Bay. 


\subsection{Need for Pollution Monitoring and Risk Communication Framework}

The findings of this study point to a need for pollution monitoring data that is current, accessible to the public, and communicated in a manner that induces responses. Although straightforward, meeting this need is challenging. Water pollution monitoring is complex and requires considerable expertise and effort (see Table S4 for details on the process of water pollution analysis in relation to the Galveston Bay). Additionally, adequate environmental monitoring requires continuity, consistency, and adequate scale-requirements that entail a significant and consistent investment of resources [78]. For this reason, there is a dearth of environmental monitoring information [79]. This is evident in the Galveston Bay where, with the exception of independent research, there is a lack of concerted water pollution monitoring. Water quality monitoring is mainly under the remit of state agencies and communicated through seafood advisories. Filling this information gap, not only in the Galveston Bay but globally, is a critical first step so that risk may be communicated effectively.

A coupled issue with lack of environmental monitoring information is the dissemination of this information to the public and policy-makers. It is important to approach information dissemination not as a process of filling information deficits, but as a process of contextualization in relation to "real world" experience [80]. In a study of awareness, use of, and attitudes toward air quality information in the United Kingdom, Bickerstaff and Walker [80] found that relevance is critical. Air quality information was criticized by residents as being overly technical in language, ambiguous due to lack of description to ease interpretation metrics, and not sufficiently specific with regards to spatial application. Additionally, air quality reports were consistently in conflict with direct personal experience. They explain [80] (p. 292):

Air-quality information is not passively received by a homogenous public body. Rather the material is contextualised and made sense of' in relation to the relevance to people's lives and the immediate and personal realities of physical encounters with air pollution. Where air-quality information and advice has little resonance with people's local experience, and where its credibility is challenged, it is quite reasonable to expect that it will be ignored or simply set alongside the many other demands on the public's attention and understanding.

Applying this approach to the issue of water quality suggests water pollution information should be provided on a relevant spatial scale (i.e., what is considered "local") and in relation to observable water quality disturbances. Further, pollution information should be approached as a collaborative effort among data users and producers [79] and possibly incorporate local knowledge through, for example, crowd-sourcing platforms [81]. Additionally, pollution information should come from credible sources where trust is established in relationships with the public. Irwin contends that effective communication of risk recognizes that information sources "will be judged alongside the perceived credibility of the source and the possibilities for practical action which are opened up for its intervention" [82]. Pollution information, therefore, should also be connected to practical actions to reduce risk. Future work should endeavor to create a risk communication framework that implements these aspects of pollution information framing and dissemination.

\subsection{Study Limitations}

The current study is limited by its cross-sectional design that captures explanatory and outcome measures at the same time. Consequently, causal relationships cannot be established. The strength of this approach for examining the association of pollution information with actions to reduce risk outweigh this limitation as this study contributes to an area of research with few empirical analyses of water quality monitoring in the context of chronic and acute environmental hazards. Furthermore, the present cross-sectional analysis provided additional information on the frequency of checking water quality information and changes to multiple types of behavior to reduce risk-critical information to move forward with further research in this area. The study is also limited by its reliance on online survey data, which restricts recruitment and participation to individuals with access to online services. 
Another limitation of this study is the reliance on a non-probability, quota-based sampling frame. Due to low response rates, high costs, and poor coverage of probability surveys, non-probability surveys are being increasingly used by researchers [83]. While quota-based sampling aims to match a panel to a set of population parameters and, therefore, enhances the representativeness of the sample, there is a critical disadvantage. Specifically, non-probability samples, including those using quotas, do not allow for calculation of margins of error that provide a measure of precision. This likely results in introducing unknown sampling biases into the survey estimates [69]. A study by the Pew Research Center [84] concluded that such biases may be reduced through the use of survey weights. Accordingly, this study includes a weight that adjusts the sample on population parameters for sex, race/ethnicity, and age using an iterative proportional fitting method by Bergmann [66]. This method is appropriate for managing the limitations of non-probability survey samples [83] but does not completely eliminate biases.

\section{Conclusions}

Hazard mitigation can take a number of forms; the present study looked at one strategy of risk reduction-building awareness [11]. Expanding the work of Reams and colleagues [14,15], this study examined how water pollution awareness and frequency of checking pollution monitoring information is associated with changes to outdoor activities and consumption of drinking water and/or seafood when water quality is poor. The results of the present study are in line with prior research, finding that behavioral changes are associated with frequent checking of water quality ratings. The findings underscore that awareness is not enough to reduce risk; rather, changes in risky behavior is only associated with very frequent engagement with pollution information. Critical to the contribution of this study is the context in which water pollution information and risk reduction activities were explored. As a hotspot of oil and gas and transportation industry activity, environmental disturbances-including the 2019 events of a chemical fire and barge collision-are not uncommon in the Galveston Bay. Residents living around the Bay, therefore, are exposed to chronic and acute water pollution. It is under these conditions that the present study found the frequency of checking water quality information to be significantly associated with changes to recreational and consumption patterns. This context has considerable implications for risk communicators, including researchers, environmental organizations, and policy-makers. Primarily the message is a cautious one-it is imperative to improve water pollution monitoring and the dissemination of this information so that risk is not ignored, normalized, or de-amplified. Investments are needed to make data collection more consistent, widespread, and on the appropriate spatial scale. While investments may come from a variety of private and public sources, there is a strong argument to be made that science-particularly in this case as it relates to human and environmental health and, thus, benefits all-should be approached as a public good, chiefly provided by the government [85]. Concerted efforts are also needed to share water pollution information in ways that are perceived as relevant, accessible, and credible to the public. Only with these developments will the potential hazard information offers for risk reduction be realized.

Supplementary Materials: The following are available online at http://www.mdpi.com/2071-1050/12/20/8695/s1, Figure S1: Environmental hazard events in the survey, Table S1: Survey sample and population proportions on sex, age, and race and ethnicity, Table S2: Logistic regression results, Table S3: Marginal effects, and Table S4: Process for the detection of polycyclic aromatic hydrocarbons (PAHs) and polychlorinated biphenyls (PCBs) in water and biota samples. Replication data and analysis files are available at: https://dataverse.harvard.edu/dataset. xhtml?persistentId=doi:10.7910/DVN/TIMHU4. 
Author Contributions: Conceptualization, A.D.R., D.H., K.K., and A.Q.; data curation, A.D.R.; formal analysis, A.D.R.; funding acquisition, A.Q.; investigation, M.K. and R.N.; methodology, A.D.R. and L.A.C.; project administration, A.Q.; resources, D.H., K.K., and A.Q.; software, A.D.R.; supervision, A.Q.; validation, A.D.R.; visualization, A.H.; writing-original draft, A.D.R., A.H., M.K., R.N., D.H., L.A.C., and A.Q.; writing-review and editing, A.D.R. and A.H. All authors have read and agreed to the published version of the manuscript.

Funding: This research was funded by the Texas General Land Office, grant number 20-057-000-B908.

Conflicts of Interest: The authors declare no conflict of interest. The funders had no role in the design of the study; in the collection, analyses, or interpretation of data; in the writing of the manuscript, or in the decision to publish the results.

\section{References}

1. Determinants of Risk: Exposure and Vulnerability. Managing the Risks of Extreme Events and Disasters to Advance Climate Change Adaptation. In A Special Report of Working Groups I and II of the Intergovernmental Panel on Climate Change (IPCC); Tignor, M., Midgley, P.M., Eds.; Cambridge University Press: Cambridge, UK; pp. 65-108.

2. Cutter, S.L.; Boruff, B.J.; Shirley, W.L. Social Vulnerability to Environmental Hazards. Soc. Sci. Q. 2003, 84, 242-261. [CrossRef]

3. EPA Local Government Advisory Committee's. EJ Best Practices for Local Government. 2015. Available online: https://www.epa.gov/sites/production/files/2015-10/documents/2015_best_practices_for_local_government. pdf (accessed on 7 September 2020).

4. Phillimore, P.; Moffatt, S. Discounted Knowledge: Local Experience, Environmental Pollution, and Health. In Researching the People's Health; Popay, J., Williams, G., Eds.; Routledge: London, UK, 1994; pp. 134-153.

5. Rohrmann, B. The risk notion: Epistemological and empirical considerations. In Integrative Risk Assessment; Stewart, M.G., Melchers, R.E., Eds.; Balkema: Rotterdam, The Netherlands, 1998; pp. 39-46.

6. Wildavsky, A.; Dake, K. Theories of Risk Perception: Who Fears What \& Why? Daedalus 1990, 119, 41-60.

7. Elliott, S.J.; Taylor, S.; Hampson, C.; Dunn, J.R.; Eyles, J.; Walter, S.; Streiner, D. 'It's Not Because You Like It Any Better ... ': Residents' Reappraisal of A Landfill Site. J. Environ. Psychol. 1997, 17, 229-241. [CrossRef]

8. Folkman, S.; Lazarus, R.S. Stress, Appraisal, and Coping; Springer Publishing: New York, NY, USA, 1984.

9. Lazarus, R.S. Coping theory and research: Past, present, and future. Psychosom. Med. 1993, 55, $234-247$. [CrossRef] [PubMed]

10. Schneider, R.O. Hazard mitigation and sustainable community development. Disaster Prev. Manag. Int. J. 2002, 11, 141-147. [CrossRef]

11. Brody, S.D.; Atoba, K.O. Flood Resiliency in the United States: Setting a framework for reducing losses. In Vulnerability and Resilience to Environmental Hazards; Fuchs, S.T., Thaler, T., Eds.; Cambridge University Press: Cambridge, UK, 2018; pp. 237-256.

12. Dengler, L. The Role of Education in the National Tsunami Hazard Mitigation Program. Nat. Hazards 2005, 35, 141-153. [CrossRef]

13. Wen, X.-J.; Balluz, L.; Mokdad, A. Association Between Media Alerts of Air Quality Index and Change of Outdoor Activity Among Adult Asthma in Six States, BRFSS, 2005. J. Community Heal. 2008, 34, 40-46. [CrossRef]

14. Reams, M.A.; Lam, N.S.N.; Cale, T.M.; Hinton, M.C.M. Applying a community resilience framework to examine household emergency planning and exposure-reducing behavior among residents of Louisiana's industrial corridor. J. Emerg. Manag. 2017, 11, 107-120. [CrossRef]

15. Reams, M.A.; Irving, J.K. Applying community resilience theory to engagement with residents facing cumulative environmental exposure risks: Lessons from Louisiana's industrial corridor. Rev. Environ. Heal. 2019, 34, 235-244. [CrossRef]

16. Busch, J. Surfer and Beachgoer Responsiveness to Coastal Water Quality Warnings. Coast. Manag. 2009, 37, 529-549. [CrossRef]

17. Jones-Bitton, A.; Gustafson, D.L.; Butt, K.; E Majowicz, S. Does the public receive and adhere to boil water advisory recommendations? A cross-sectional study in Newfoundland and Labrador, Canada. BMC Public Heal. 2015, 16, 1-7. [CrossRef] [PubMed]

18. Vedachalam, S.; Spotte-Smith, K.T.; Riha, S.J. A meta-analysis of public compliance to boil water advisories. Water Res. 2016, 94, 136-145. [CrossRef] [PubMed] 
19. National Oceanic and Atmospheric Administration Raw Incident Data. Available online: https://incidentnews. noaa.gov/raw/index (accessed on 18 September 2020).

20. Armstrong, N.E. The Ecology of Open-Bay Bottoms of Texas: A Community Profile; US Department of the Interior Fish and Wildlife Service: Washington, DC, USA, 1987.

21. Rayson, M.D.; Gross, E.S.; Fringer, O.B. Modeling the tidal and sub-tidal hydrodynamics in a shallow, micro-tidal estuary. Ocean Model. 2015, 89, 29-44. [CrossRef]

22. Johnson, J.S.; Cairns, D.M.; Houser, C. Coastal Marsh Vegetation Assemblages of Galveston Bay: Insights for the East Texas Chenier Plain. Wetlands 2013, 33, 861-870. [CrossRef]

23. Freeman, L.A.; Corbett, D.R.; Fitzgerald, A.M.; Lemley, D.A.; Quigg, A.; Steppe, C.N. Impacts of Urbanization and Development on Estuarine Ecosystems and Water Quality. Estuaries Coasts. 2019, 42, 1821-1838. [CrossRef]

24. The Galveston Bay Plan (2nd ed.). Available online: https://gbep.texas.gov/wp-content/uploads/2020/05/ CCMP_2ndEdition_FINAL-DRAFT.pdf (accessed on 7 September 2020).

25. Balderrama, E.; Duran, H.; Guzman, R.; Jankowski, P.; Martinez, R.; Pherigo, J.; Suljic, B. Houston Facts; Greater Houston Partnership: Houston, TX, USA, 2020.

26. Steichen, J.L.; Windham, R.; Brinkmeyer, R.; Quigg, A. Ecosystem under pressure: Ballast water discharge into Galveston Bay, Texas (USA) from 2005 to 2010. Mar. Pollut. Bull. 2012, 64, 779-789. [CrossRef]

27. Steichen, J.L.; Denby, A.; Windham, R.; Brinkmeyer, R.; Quigg, A. A Tale of Two Ports: Dinoflagellate and Diatom Communities Found in the High Ship Traffic Region of Galveston Bay, Texas (USA). J. Coast. Res. 2015, 31, 407-416. [CrossRef]

28. Houston Advanced Research Center. Oil Spills-A Continual Risk for Galveston Bay Habitats. Available online: https://www.harcresearch.org/features/Oils_Spills_a\%20_Continual_Risk_for_Galveston_Bay_ Habitats\#: \{\}:text=The\%20spill\%20measured\%2044\%2C100\%20gallons,Spill\%20Prevention\%20and \% 20Response\%20Program (accessed on 7 September 2020).

29. Williams, A.K.; Bacosa, H.P.; Quigg, A. The impact of dissolved inorganic nitrogen and phosphorous on responses of microbial plankton to the Texas City "Y" oil spill in Galveston Bay, Texas (USA). Mar. Pollut. Bull. 2017, 121, 32-44. [CrossRef]

30. Biddinger, G.R.; Gloss, S.P. The Importance of Trophic Transfer in the Bioaccumulation of Chemical Contaminants in Aquatic Ecosystems. In Residue Reviews; Springer: New York, NY, USA, 1984; pp. 103-145.

31. El-Shahawi, M.; Hamza, A.; Bashammakh, A.; Al-Saggaf, W. An overview on the accumulation, distribution, transformations, toxicity and analytical methods for the monitoring of persistent organic pollutants. Talanta 2010, 80, 1587-1597. [CrossRef]

32. Jensen, S.; Johnels, A.G.; Olsson, M.; Otterlind, G. DDT and PCB in Marine Animals from Swedish Waters. Nature 1969, 224, 247-250. [CrossRef]

33. Livingstone, D. The fate of organic xenobiotics in aquatic ecosystems: Quantitative and qualitative differences in biotransformation by invertebrates and fish. Comp. Biochem. Physiol. Mol. Integr. Physiol. 1998, 120, $43-49$. [CrossRef]

34. Peterson, C.H.; Rice, S.D.; Short, J.W.; Esler, D.; Bodkin, J.L.; Ballachey, B.E.; Irons, D.B. Long-Term Ecosystem Response to the Exxon Valdez Oil Spill. Science 2003, 302, 2082-2086. [CrossRef] [PubMed]

35. Bejarano, A.C.; Michel, J. Large-scale risk assessment of polycyclic aromatic hydrocarbons in shoreline sediments from Saudi Arabia: Environmental legacy after twelve years of the Gulf war oil spill. Environ. Pollut. 2010, 158, 1561-1569. [CrossRef] [PubMed]

36. Randolph, R.; Hardy, J.T.; Fowler, S.W.; Price, A.R.; Pearson, W.H. Toxicity and persistence of nearshore sediment contamination following the 1991 Gulf War. Environ. Int. 1998, 24, 33-42. [CrossRef]

37. Yeager, K.M.; Santschi, P.H.; Rifai, H.S.; Suarez, M.P.; Brinkmeyer, R.; Hung, C.C.; Schindler, K.J.; Andres, M.J.; Weaver, E.A. Dioxin chronology and fluxes in sediments of the Houston Ship Channel, Texas: Influences of non-steady-state sediment transport and total organic carbon. Environ. Sci. Technol. 2007, 41, 5291-5298. [CrossRef]

38. Howell, N.L.; Suarez, M.P.; Rifai, H.S.; Koenig, L. Concentrations of polychlorinated biphenyls (PCBs) in water, sediment, and aquatic biota in the Houston Ship Channel, Texas. Chemosphere 2008, 70, 593-606. [CrossRef] 
39. Oziolor, E.M.; Apell, J.N.; Winfield, Z.C.; Back, J.A.; Usenko, S.; Matson, C.W. Polychlorinated biphenyl (PCB) contamination in Galveston Bay, Texas: Comparing concentrations and profiles in sediments, passive samplers, and fish. Environ. Pollut. 2018, 236, 609-618. [CrossRef]

40. Correa, O.; Rifai, H.; Raun, L.; Suárez, M.; Koenig, L. Concentrations and vapor-particle partitioning of polychlorinated dibenzo-p-dioxins and dibenzofurans in ambient air of Houston, TX. Atmos. Environ. 2004, 38, 6687-6699. [CrossRef]

41. Raun, L.H.; Correa, O.; Rifai, H.; Suárez, M.; Koenig, L. Statistical investigation of polychlorinated dibenzo-p-dioxins and dibenzofurans in the ambient air of Houston, Texas. Chemosphere 2005, 60, 973-989. [CrossRef]

42. Correa, O.; Raun, L.; Rifai, H.; Suárez, M.; Holsen, T.; Koenig, L. Depositional flux of polychlorinated dibenzo-p-dioxins and polychlorinated dibenzofurans in an urban setting. Chemosphere 2006, 64, 1550-1561. [CrossRef]

43. T.D.S.H.S. Characterization of Potential Adverse Health Effects Associated with Consuming Fish or Blue Crab, from Clear Creek: Harris County, Texas; Texas Department of State Health Services, Seafood and Aquatic Life Group: Austin, TX, USA, 2009.

44. Lester, L.J.; Gonzalez, L.A. (Eds.) The State of the Bay: A Characterization of the Galveston Bay Ecosystem, 3rd ed.; Texas Commission on Environmental Quality, Galveston Bay Estuary Program: Houston, TX, USA, 2011.

45. Harris County Fire Marshall's Office Final Report: Intercontinental Terminals Company Tank Farm Fire. Available online: https://assets.documentcloud.org/documents/6570257/ITC-Final-Report.pdf (accessed on 7 September 2020).

46. Trevizo, P. Report: Investigators rule Deer Park fire an accident, cite equipment failure. Houston Chronicle, 10 December 2019.

47. Trevizo, P. The ITC fire created 20 million gallons of waste. Getting rid of it is no easy task. Houston Chronicle, 21 July 2019.

48. Despart, Z.; Ketterer, S. Investigation set to begin amid smoldering Deer Park chemical tanks. Chron, 20 March 2019.

49. Rogalski, J. ITC chemical facility did not have gas alarms or shutoff valves when massive fire erupted. KHOU, 30 October 2019.

50. Rice, J. Texas A\&M water researchers find waxy residue near Deer Park disaster. Houston Public Media, 28 March 2019.

51. National Oceanic Atmospheric Administration. ORER Responds to Barge Collision in Houston Ship Channel; NOAA Office of Response and Restoration: Silver Spring, MD, USA, 13 March 2019.

52. Trevizo, P. Quick response limits impact of Ship Channel spill. Houston Chronicle, 10 June 2019.

53. Dougherty, M. "Stay away from the water"|Safety zone around chemical spill at Houston Ship Channel expands. KHOU, 12 May 2019.

54. Texas Commission on Environmental Quality. Available online: https://www.tceq.texas.gov/response/itcmonitoring-water-quality (accessed on 13 September 2020).

55. Loomis, D.; Guyton, K.Z.; Grosse, Y.; El Ghissassi, F.; Bouvard, V.; Benbrahim-Tallaa, L.; Guha, N.; Vilahur, N.; Mattock, H.; Straif, K. Carcinogenicity of benzene. Lancet Oncol. 2017, 18, 1574-1575. [CrossRef]

56. E.L.I. City of Deer Park -ITC Water Check. Available online: http://www.deerparktx.gov/DocumentCenter/ View/7315/2019-03-27--Deerpark--ITC-Water-Check (accessed on 7 September 2020).

57. I.A.R.C. Crude Oil 1989. Available online: http://www.inchem.org/documents/iarc/vol45/45-02.html (accessed on 7 September 2020).

58. M.S.D.S. Crude Oil. 2010. Available online: https://gulfresearchinitiative.org/wp-content/uploads/2012/05/ Sweet-Petroleum-Crude-Oil-MC-252.081410.pdf (accessed on 7 September 2020).

59. Aguilera, F.; Méndez, J.; Pásaro, E.; Laffon, B. Review on the effects of exposure to spilled oils on human health. J. Appl. Toxicol. 2010, 30, 291-301. [CrossRef]

60. Louisiana Department of Health and Hospitals 2010 Oil Spill Surveillance Summary Report. Available online: https://ldh.la.gov/assets/docs/SurveillanceReports/OilSpillHealth/_OilSpillSurveillance2010_17.pdf (accessed on 7 September 2020). 
61. Peres, L.C.; Trapido, E.; Rung, A.L.; Harrington, D.J.; Oral, E.; Fang, Z.; Fontham, E.; Peters, E.S. The Deepwater Horizon Oil Spill and Physical Health among Adult Women in Southern Louisiana: The Women and Their Children's Health (WaTCH) Study. Environ. Heal. Perspect. 2016, 124, 1208-1213. [CrossRef]

62. Rung, A.L.; Gaston, S.A.; Oral, E.; Robinson, W.T.; Fontham, E.; Harrington, D.J.; Trapido, E.; Peters, E.S. Depression, Mental Distress, and Domestic Conflict among Louisiana Women Exposed to the Deepwater Horizon Oil Spill in the WaTCH Study. Environ. Heal. Perspect. 2016, 124, 1429-1435. [CrossRef] [PubMed]

63. Strelitz, J.; Engel, L.S.; Kwok, R.K.; Miller, A.; Blair, A.; Sandler, D.P. Deepwater Horizon oil spill exposures and nonfatal myocardial infarction in the GuLF STUDY. Environ. Heal. 2018, 17, 69. [CrossRef] [PubMed]

64. Kwok, R.K.; McGrath, J.; Lowe, S.R.; Engel, L.S.; Jackson, W.B.; Curry, M.D.; Payne, J.; Galea, S.; Sandler, D.P. Mental health indicators associated with oil spill response and clean-up: Cross-sectional analysis of the GuLF STUDY cohort. Lancet Public Heal. 2017, 2, e560-e567. [CrossRef]

65. U.S. Census Bureau. American Community Survey 2014-2018 (5-Year Estimates) for Population (SE: A00001), Sex (SE: A02001 and SE: A02002), and Race (SE: A3001, SE: A4001). Prepared by Social Explorer. Available online: www.socialexplorer.com (accessed on 15 May 2020).

66. Bergmann, M. IPFWEIGHT: Stata Module to Create Adjustment Weights for Surveys; Statistical Software Components S457353; Department of Economics, Boston College: Boston, MA, USA, 2011.

67. Izrael, D.; Battaglia, M.P.; Frankel, M.R. Extreme survey weight adjustment as a component of sample balancing (aka raking). In Proceedings of the SAS Global Forum 2009, Washington, DC, USA, 22-25 March 2009.

68. National Household Travel Survey 2017 Weighting Report. Available online: https://nhts.ornl.gov/assets/ 2017\%20NHTS\%20Weighting\%20Report.pdf (accessed on 7 September 2020).

69. Battaglia, M. Nonprobability Sampling. In Encyclopedia of Survey Research Methods; Lavrakas, P.J., Ed.; SAGE Publications, Inc.: Thousand Oaks, CA, USA, 2008; pp. 524-537.

70. Texas Parks and Wildlife Department Beach Access Points. Available online: https://glo.texas.gov/land/landmanagement/gis/index.html (accessed on 11 September 2020).

71. Wakefield, S.E.; Elliott, S.J.; Cole, D.C.; Eyles, J.D. Environmental risk and (re)action: Air quality, health, and civic involvement in an urban industrial neighbourhood. Heal. Place 2001, 7, 163-177. [CrossRef]

72. Nelson, D.R.; Adger, W.N.; Brown, K. Adaptation to Environmental Change: Contributions of a Resilience Framework. Annu. Rev. Environ. Resour. 2007, 32, 395-419. [CrossRef]

73. Carraway, T.M. An Analysis of the Influences on Household-Level Adaptations to Environmental Hazards. Master's Thesis, Louisiana State University, Baton Rouge, LA, USA, December 2013.

74. Peng, C.-Y.J.; Lee, K.L.; Ingersoll, G.M. An Introduction to Logistic Regression Analysis and Reporting. J. Educ. Res. 2002, 96, 3-14. [CrossRef]

75. Archer, K.J.; Lemeshow, S. Goodness-of-fit Test for a Logistic Regression Model Fitted using Survey Sample Data. Stata J. 2006, 6, 105-197. [CrossRef]

76. Mood, C. Logistic Regression: Why We Cannot Do What We Think We Can Do, and What We Can Do about It. Eur. Sociol. Rev. 2009, 26, 67-82. [CrossRef]

77. Burger, J. Consumption Advisories and Compliance: The Fishing Public and the Deamplification of Risk. J. Environ. Plan. Manag. 2000, 43, 471-488. [CrossRef]

78. Biber, E. The Problem with Environmental Monitoring. Univ. Colo. Law Rev. 2011, 83.

79. O'Malley, R.; Marsh, A.S.; Negra, C. Closing the environmental data gap. Issues Sci. Technol. 2009, $25,69-74$.

80. Bickerstaff, K.; Walker, G. Clearing the smog? Public responses to air-quality information. Local Environ. 1999, 4, 279-294. [CrossRef]

81. Younis, E.M.G.; Kanjo, E.; Chamberlain, A. Designing and evaluating mobile self-reporting techniques: Crowdsourcing for citizen science. Pers. Ubiquitous Comput. 2019, 23, 329-338. [CrossRef]

82. Iwrin, A. Citizen Science: A Study of People, Expertise and Sustainable Development; Routledge: New York, NY, USA, 1995.

83. Baker, R.; Brick, J.M.; Bates, N.A.; Battaglia, M.; Couper, M.P.; Dever, J.A.; Gile, K.J.; Tourangeau, R. Summary Report of the AAPOR Task Force on Non-probability Sampling. J. Surv. Stat. Methodol. 2013, 1, 90-143. [CrossRef] 
84. Pew Research Center Evaluating Online Probability. Available online: https://www.pewresearch.org/ methods/2016/05/02/evaluating-online-nonprobability-surveys/ (accessed on 19 January 2020).

85. Ross, A.D.; Struminger, R.; Winking, J.; Wedemeyer-Strombel, K.R. Science as a Public Good: Findings from a Survey of March for Science Participants. Sci. Commun. 2018, 40, 228-245. [CrossRef]

Publisher's Note: MDPI stays neutral with regard to jurisdictional claims in published maps and institutional affiliations.

(C) 2020 by the authors. Licensee MDPI, Basel, Switzerland. This article is an open access article distributed under the terms and conditions of the Creative Commons Attribution (CC BY) license (http://creativecommons.org/licenses/by/4.0/). 